\title{
SCLEROTIC METAPHYSEAL BANDS SECONDARY TO DENOSUMAB
}

\section{Bowen M., Botchu R., James S.L., Davies A.M.}

here is a long list of differential diagnoses for sclerotic metaphyseal bands identified on radiographs. We present a case of generalised sclerotic metaphyseal bands that occurred following the administration of denosumab, a human monoclonal antibody, used to treat an aggressive aneurysmal bone cyst (ABC).

The Royal Orthopedic Hospital, Bristol Road South, Northfield. Birmingham, UK. aphyseal.

Keywords: denosumab, radiographs, aggressive aneurysmal bone cyst, sclerotic met-

Corresponding author: Botchu R., e-mail: drbrajesh@yahoo.com

For citation: Bowen M., Botchu R., James S.L., Davies A.M. Sclerotic metaphyseal bands secondary to denosumab. REJR 2019; 9(3):235-237. DOI:10.21569/2222-7415-20199-3-235-237.

$\begin{array}{lll}\text { Статья получена: } \quad 11.06 .19 & \text { Статья принята: } & 11.07 .19\end{array}$

\section{СКАЕРОТИЧЕСКИЕ ИЗМЕНЕНИЯ МЕТАФИЗОВ КОСТЕЙ ПРИ АЕЧЕНИИ АЕНОСУМАБОМ (ЧЕАОВЕЧЕСКИМИ МОНОКАОНААЬНЫМИ АНТИТЕААМИ)}

\author{
Боуэн М., Ботчу Р., Ажеймс С.А., Аэвис А.М.
}

уществует длинный список дифференциальных диагнозов при склеротических изменениях метафизов костей, определяющихся на рентгенограммах. Мы представляем клинический случай генерализованных склеротических изменений метафизов костей, которые появились после введения деносумаба (человеческих моноклональных антител), используемых при цечении агрессивных аневризматических кист костей.

КАючевые слова: деносумаб, рентгенограммы, агрессивная аневризматическая киста кости, склеротический метафиз.

Контактный автор: Ботчу Р., эмектронная почта: drbrajesh@yahoo.com

Для иитирования: Боуэн М., Ботчу Р., Джеймс С.А., Дэвис А.М. Склеротические изменения метафизов костей при лечении деносумабом (человеческими моноклональньми антителами). REJR 2019; 9(3):235-237. DOI:10.21569/2222-7415-2019-9-3-235-237.

Received: 11.06.19 Accepted: 11.07.19
Королевская ортопедическая больница, Нортфилд. Бирмингем, Вемикобритания 


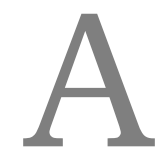

13-year-old male was referred to our hospital with a lytic lesion, identified on radiographs, in the right proximal tibial metaphysis. Imaging features on the radiographs and MRI were considered typical of an ABC which was confirmed histologically. Initial surgical management involved "curopsy", a technique whereby percutaneous curettage is performed at the time of biopsy [1]. On follow-up im-

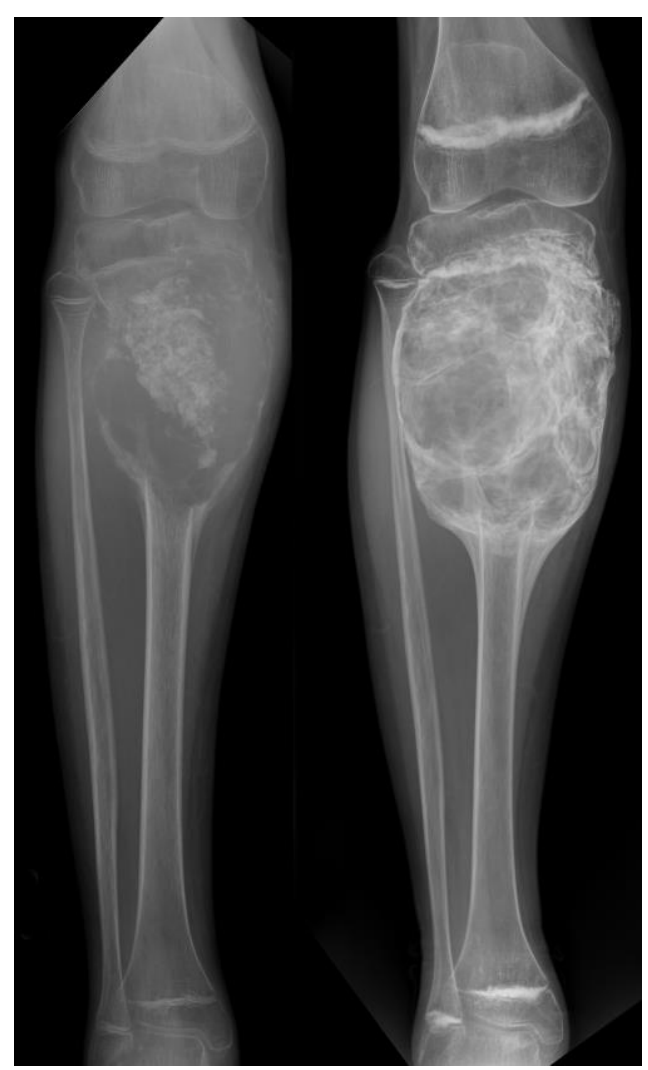

Fig. 1 (Рис. 1)

Fig. 1. X-ray, AP view.

$\mathrm{A}$ - AP radiograph demonstrating the $\mathrm{ABC}$ in the right proximal tibial metadiaphyseal region which continued to increase in size following curettage and bone grating.

$\mathrm{B}$ - peripheral consolidation of the $\mathrm{ABC}$ with sclerotic metaphyseal bands on an AP radiograph performed 7 months following commencement of denosumab.

Рис. 1. Рентгенограмма, переАняя проекция.

А - аневризматическая киста кости в правом проксимальном метадиафизе большеберцовой кости, которая продолжала увеличиваться в размерах после выскабливания.

Б - периферическая консолидация аневризматической кисты кости со склеротическими изменениями метафиза кости на рентгенограмме, выполненной через 7 месяцев после начала приема деносумаба. aging 3 months later the lesion had significantly increased in size and was invading the growth plate of the proximal tibia. The patient underwent further curettage and bone grafting of the lesion but despite this the ABC continued to dramatical ly increase in size (Fig. 1A). Following discussion at the orthopaedic oncology multidisciplinary team meeting, the patient was commenced on denosumab (Prolia, XGEVA). Radiographs performed 7 months later showed that there had been considerable peripheral consolidation of the ABC (Fig. 1B). On the same radiographs it was noted that there were sclerotic bands in the metaphyses of the distal femur, tibia and fibula.

A radiograph of the left hand and wrist obtained at the same time for the purpose of bone age estimation revealed that the sclerotic metaphyseal bands were also present in the radius, ulna, metacarpals and phalanges (Fig. 2) indicating a widespread process secondary to denosumab.

\section{Discussion.}

Aneurysmal bone cysts are benign expansile lesions which can be either primary or secondary to other benign tumours. At present, curettage with or without bone grafting is usually the preferred management strategy. However, emerging alternative treatment options include "curopsy" and denosumab [2].

Denosumab is a human monoclonal antibody which decreases bone resorption by inhibiting osteoclast activation [3]. The current indications for the use of denosumab, as per the $\mathrm{Na}$ tional Institute for Health and Care Excellence, include the treatment of osteoporosis in postmenopausal women and in men at increased risk of fractures, the treatment of bone loss associated with hormone ablation in men with prostate cancer at increased risk of fractures, the prevention of skeletal related events in patients with bone metastases from solid tumours and the treatment of giant cell tumour of bone that is unresectable or where surgical resection is likely to result in severe morbidity in adults and skeletally mature adolescents [4]. At present, the use of denosumab in children is not recommended as data on its safety and efficacy in this population is limited [5]. As aneurysmal bone cysts express osteoclastic markers, therapies which inhibit osteoclastic activity such as denosumab have begun to be used in their treatment. However, further research into the use of denosumab in patients with aneurysmal bone cysts is required [3].

Sclerotic metaphyseal bands occur when the balance between osteoblastic and osteoclastic activity in the growth plates of skeletally immature patients is compromised [6]. Sclerotic metaphyseal bands are not expected to appear following growth plate fusion.

Given that denosumab inhibits osteoclastic 


\section{RUSSIAN ELECTRONIC JOURNAL OF RADIOLOGY}

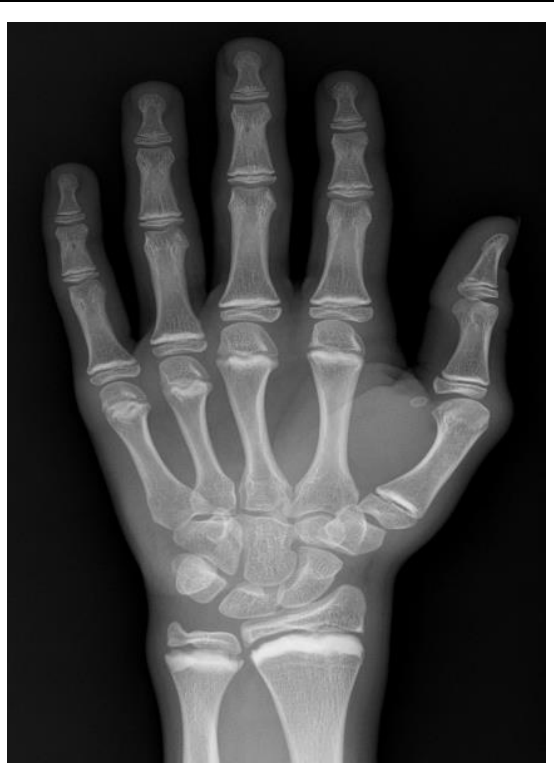

Fig. 2 (Рис. 2)

\section{Fig. 2. X-ray. PA view.}

Radiograph performed at the same time as Fig. 1b demonstrating sclerotic metaphyseal bands in the left hand and wrist.

\section{Рис. 2. Рентгенограмма, заАняя проекция.}

Рентгенограмма, выполненная одновременно с исследованием на Рис. 1b. Отмечаются скмеротические метафизарные изменения мевой руки и запястья.

\section{References:}

1. Reddy K, Sinnaeve F, Gaston C, Grimer R, Carter S. Aneurysmal Bone Cysts: Do Simple Treatments Work? Clinical Orthopaedics and Related Research. 2014; 472 (6): 1901-1910.

2. Park H, Yang S, Sheppard W, Hegde V, Zoller S, Nelson S et al. Current Management of Aneurysmal Bone Cysts. Current Reviews in Musculoskeletal Medicine. 2016; 9 (4): 435-444.

3. Savvidou O, Bolia I, Chloros G, Papanastasiou J, Koutsouradis P, Papagelopoulos P. Denosumab: Current Use in the Treatment of Primary Bone Tumors. Orthopedics. 2017; 40 (4): 204-210.

4. DENOSUMAB, Drug, BNF Provided by NICE [Internet]. Bnf.nice.org.uk. 2017 [cited 31 October 2017]. Available from: activation, the development of sclerotic metaphyseal bands in the patient being managed in our hospital as described above can be attributed to denosumab. This is one of few reported cases of

sclerotic metaphyseal bands secondary to denosumab in English literature. The other cases have occurred in patients receiving denosumab for a giant cell tumour and fibrous dysplasia $[7,8]$.

Two further skeletally immature patients with benign bone tumours have been treated with denosumab at our hospital. In neither case do follow-up radiographs show evidence of sclerotic metaphyseal bands indicating that this is not a universal phenomenon.

Other side-effects of denosumab include hypocalcaemia, osteonecrosis of the jaw, atypical femoral fractures and transformation of giant cell tumours to osteosarcomas. Rebound hypercalcaemia can occur following the cessation of denosumab [3].

\section{Learning Points.}

1. Denosumab acts by inhibiting osteoclastic activation and therefore should be included in the differential diagnoses of sclerotic metaphyseal bands which occur when the balance between osteoblastic and osteoclastic activity is compromised.

2. Further research into the use of denosumab in children and aneurysmal bone cysts is required given that it can have several significant side effects. https://bnf.nice.org.uk/drug/denosumab.html

5. Boyce A. Denosumab: an Emerging Therapy in Pediatric Bone Disorders. Current Osteoporosis Reports. 2017; 15 (4): 283-292. 6. Raber S. The Dense Metaphyseal Band Sign. Radiology. 1999; 211 (3): 773-774.

7. Kobayashi E, Setsu N. Osteosclerosis induced by denosumab. The Lancet. 2015; 385 (9967): 539.

8. Wang H, Boyce A, Tsai J, Gafni R, Farley F, Kasa-Vubu J et al. Effects of Denosumab Treatment and Discontinuation on Human Growth Plates. The Journal of Clinical Endocrinology \& Metabolism. 2014; 99 (3): 891-897. 